\title{
FACTORS AFFECTING EMPLOYEE-BASED BRAND EQUITY: EVIDENCE FROM CHINA
}

\author{
TAHIR MUMTAZ AWAN \\ Sun Yat-sen Business School \\ Peoples Republic of China \\ HAIZHONG WANG \\ Department of Marketing \\ Sun Yat-sen Business School \\ Peoples Republic of China \\ XIAOLIN LI \\ Department of Marketing \\ Guangdong University of Finance $\mathcal{E}$ Economics \\ Peoples Republic of China
}

\begin{abstract}
Employee-based brand equity (EBBE) has been receiving increasing attention in recent years. However, most studies focus on the construct definition and scale development, as well as the effects that EBBE may have on corporate performance. Few studies try to identify the source of EBBE, or in other words, the antecedents of EBBE. The major study of the antecedents of $E B B E$ is King and Grace's model (2010), which is restricted to the service industry. As this research is cultural context-dependent, it is necessary to test the framework of King and Grace's model (2010) in other regions or industries. Replication studies are important for the generalizability of strategic management theories as reputed journals such as the Academy of Management Journal (AMJ) and the Strategic Management Journal (SMJ) have proposed. Therefore, this study was designed to test King and Grace's model (2010) in an eastern cultural context (China) and covers several nonservice sector industries. The results confirmed King and Grace's model to a high extent, which has significant implications for firms in developing countries.
\end{abstract}

Keywords: Employee-based brand equity, Brand management, China, Employee behavior, Competitive advantage.

Received: 8/03/2017

Revised: 15/11/2017

Accepted: 13/12/2017 


\section{Introduction}

Brands are useful weapons for companies to win over customers. The management of firms has recognized the importance of brands and the necessity of investing in brands and customers (Christodoulides \& de Chernatony, 2010). Consumer-based brand equity experienced increasing concern; but the role of employees is also attracting more and more attention (King \& Grace 2010). The creation of a strong brand and the deliverance of perceived service quality are premised by employees' ability to deliver on customer expectations (Lings, 2004). As more and more attention shifts towards employees, scholars claim that it is necessary to study brand equity from the perspective of employees, which is called Employee-based Brand Equity (EBBE) (King \& Grace 2010). The enhancement of EBBE contributes towards attracting skilled talent to join firms, and employees' skills and knowledge provide a competitive advantage for a firm (King, Grace, \& Funk, 2012). At the same time, employees' identification with firms may contribute to customer satisfaction since they directly interact with customers or clients (Poulis \& Wisker 2016).

The existing literature mostly focuses on the measurement of EBBE (King \& Grace, 2010; King, Grace, \& Funk, 2012), or the effects of EBBE on corporate performance (Priyadarshi, 2011; Schlager, Bodderas, Maas, \& Cachelin, 2011). Few studies attempt to explore factors affecting EBBE which is important since management decisions aimed at enhancing employee satisfaction depends on recognition of those factors (King \& Grace, 2010). The studies on antecedents of EBBE differ from each other. Biswas and Suar identify 8 factors which include realistic job previews, perceived organizational support, equity in reward administration, perceived organizational prestige, organizational trust, leadership of top management, psychological contract obligations, and corporate social responsibility (Biswas \& Suar, 2016). King and Grace consider six factors that may influence EBBE (King \& Grace, 2010). These factors are human factors, openness, knowledge dissemination, role clarity, brand commitment and information generation. The advantages of the latter lie in its introduction of two contextual constructs (openness and human factor) to the model of EBBE by employing the connectionist perspective (King \& Grace, 2010).

However, King and Grace's model (2010) is based on the connectionist perspective, which covers a context-based cognitive psychology paradigm. At the same time, cognition does not occur in isolation 
from larger cultural contexts. All cognitive activities are shaped by the culture and by the context in which they occur (Galotti, 2017). In other words, King and Grace's model is tested by data from Australia and is focused on the service industry, which may not apply to other countries or regions or to other non-service industries. It is important to test the model in other regions and industries so as to enhance the model's generalizability. The present paper was designed to test King and Grace's (2010) model through replication research. The replication study is an indispensable ingredient in the scientific process (Amir \& Sharon, 1990; Eden, 2002). For strategic management, replication is employed as scientific testing for validity, generalizability and usefulness (Hubbard, Vetter, \& Little, 1998). For journals such as AMJ and SMJ, replication research is often used to test the generalizability of management theories (Ghosh, Ranganathan, \& Rosenkopf, 2016; Howard, Withers, Carnes, \& Hillman, 2016; Kline \& Peters, 1991). In fact, issue 11 of SMJ in 2016 was a special issue focusing on replication research. Therefore, it is important to do replication research of King and Grace's (2010) model so as to enhance the generalizability and to set references for firms from other regions or industries. To be specific, the present study tried to test the model in a rapidly developing country, China, whose culture is quite different from western countries like Australia. At the same time, we extended the industries to cover manufacturing. Based on the data from China, the results show that human factors, openness, knowledge dissemination, role clarity and brand commitment have significant direct or indirect effects on EBBE, and information generation has a peripherally significant indirect effect on EBBE. The results of this study have important implications for firms trying to enhance EBBE.

\section{Literature Review}

Employee-based brand equity comes from the application of marketing principles in the field of human resource management (Maurer, Howe, \& Lee, 1992), where employees are considered as stakeholders influenced by company image (Abratt, 1989) and have an impact on company identity (Stuart, McCutcheon, Handfield, McLachlin, \& Samson, 2002). By doing this, employees are viewed as internal customers and their jobs as internal products (Berry, 2000; Schneider \& Bowen, 1993). The previous studies show that employees contribute to corporate performance through the interaction which occurs among company, employees, and customers (King \& Grace, 2009). Therefore, EBBE can be defined as the value a brand 
provides to a firm through its effects on the attitudes and behaviors of its employees (Tavassoli, Sorescu, \& Chandy, 2014). The existing literature focuses on two aspects of EBBE: the measurement of EBBE and its consequences.

As the definitions of EBBE vary in the existing literature, the measurement of EBBE also has a variety of scales. For example, King and Grace (2009) consider that EBBE can be defined as the differential effect that brand knowledge has on an employee's response to their work environment. Therefore, EBBE requires the translation of the brand identity in a way that is meaningful to the employee in the context of their roles and responsibilities (King \& Grace, 2009). In contrast, Cardy, Miller and Ellis (2007) borrowed the philosophy of segmenting customers put forward by Rust and Oliver (2000), and do not view all workers as equally valuable to an organization (Cardy, Miller, \& Ellis, 2007). They define EBBE into three types of equity: value equity, brand equity and retention equity, and segment workers into categories representing their level of value to an organization which is closely tied to performance. Thus, the strategic plan should underscore"Platinum" employees.

Second, most studies agree on the role of EBBE on corporate performance. According to King et al. (2012) EBBE includes three components: brand consistent behavior, brand endorsement and brand allegiance. These three components are vital for organizational productivity, and account for a successful internal brand. Poulis and Wisker (2016) subsequently contended that EBBE is a kind of intangible asset for firms. It serves as an effective tool for creating and maintaining strong brands (de Chernatony, 1999; Poulis \& Wisker, 2016), as well as successful marketing practices (Brexendorf \& Kernstock, 2007).

Finally, whereas EBBE serves as an important tool for marketing success, few studies explore what contributes to EBBE, which remains a huge opportunity for the marketing circle (Cadman, Carter, \& Lynch, 2012). Earlier studies show that EBBE is basically the effect of brand knowledge that an employee has on himself in response to the work environment and job satisfaction (Meredith, Steward, \& Lewis, 2011). These features result in the retention and motivation for employees to deliver brand promise to customers (Brown \& Lam, 2008). Therefore, EBBE represents a relationship that exists between employees and the organization. How this relationship develops will affect customer satisfaction and the corporate performance accordingly (De 
Chernatony, Cottam, \& Segal-Horn, 2006; Lings, 2004; De Chernatony \& Cottam, 2006), that is, EBBE is related to organizational practice as well as the interactions between employees and organizations, which may include both internal and external factors that contribute to the coordination of employees (Yang \& Lan, 2009). King and Grace (2010) identified six organizational factors that contribute to EBBE as mentioned above.

The first factor of King and Grace's model is to collect and disseminate information. Information collection is concerned with the collection of employee information so that the organization can have an appreciation or understanding of the employee market. The dissemination of information is related to equipping employees with knowledge to satisfy customer expectations that are formed as a result of the brand's communicated identity. The brand-related information (brand knowledge) provides a direction to ensure that employees are able to successfully carry out their roles and responsibilities (King \& Grace, 2005). Reed, Forehand, Puntoni, and Warlop (2012) identified that brand knowledge will help employees communicate corporate information so as to enhance better interaction between employees, as well as between employees and customers. Additionally, a good knowledge of brand helps the employees to know it better and make them understand its promise to its customers (Cox, Zagelmeyer, \& Marchington, 2006).

For the success of brand information dissemination, the organization should pay attention to two aspects: the openness and human factors (King \& Grace, 2010), because it is the creation of such an environment that enhances an employee's ability and motivation to acquire and develop relevant and meaningful brand knowledge (Aselage \& Eisenberger, 2003). Openness is defined as the extent to which an employee is receptive to organizational dialogue, and the " $\mathrm{H}$ " factor or the "human" factor, the extent to which an employee perceives that the organization treats them like a human being. While openness is manifested through management support, organizational socialization, employee attitudes towards their jobs and employee involvement, " $\mathrm{H}$ " factor reflects the relational considerations necessary for successful exchanges. There is evidence about employee attitudes toward job satisfaction being an important factor in organizational commitment and significant implications are found in various fields of organizational behavior and human resource management (Kumar, 2011). 
Furthermore, for brand knowledge to be effectively communicated among employees and internalized as their beliefs, management must try hard to deal with two factors: role conflict/ambiguity and employee's commitment. It is significant that an increase in role ambiguity affects performance detrimentally (Babin \& Boles, 1996). Furthermore, to ensure that employees are not only able, but also have a genuine desire to deliver the brand promise, the level of employee brand commitment becomes an important indicator of employee brand knowledge effects (Babin \& Boles, 1996).

\section{Hypothesis Development}

The human factor represents the degree to which the employees of the organization perceive that the firm is treating them as human beings and providing them their basic rights. The human factor has an impact on openness in a positive manner. Employees are observed to be more satisfied and working with full attention and zeal when their human rights are respected (Mowday, Porter, \& Steers, 2013). The satisfaction of employees also increases the information generation (Hall, 2008). Based on this logic it was hypothesized that the $\mathrm{H}$ factor positively affects openness and information generation and consequently the two hypotheses below were formulated.

\section{H1: The " $H$ " factor has a significant positive effect on openness.}

\section{H2: The " $\mathrm{H}$ " factor has a significant positive effect on information generation.}

Employee satisfaction is somehow concerned with its openness, and the relationship stated above in the two hypotheses is of important nature. When employees are more satisfied it automatically increases the organizational benefit. The benefits are discussed in the literature in both monetary and non-monetary terms (Mizik \& Jacobson, 2008).

\section{H3: Openness has a significant positive effect on information generation.}

Knowledge dissemination is the emplyoee's level of perception that brand knowledge has been transferred from the organization to the employee; it develops the trust of the employees, so its positive relationship with the $\mathrm{H}$ factor is noticed (Gagnon, 2011). Furthermore 
it also holds great importance in motivating the employees. It is expected that information generation (Schütze and Schütze, 2012) has a positive relationship with knowledge dissemination as both these features increase the motivation and the satisfaction of the employees.

H4: The " $H$ " factor has a significant positive effect on knowledge dissemination.

H5: Information generation has a significant positive effect on knowledge dissemination.

The process of information generation through the employees creates self-confidence in them. It also creates clarity in their jobs (Bray, Beauchamp, Eys, \& Carron, 2005) and they become more valuable / useful for the organizations. Additionally, knowledge dissemination also positively affects role clarity (Carter, 2010; Greco, Laschinger, \& Wong, 2006). When the employees have clarity of their roles due to brand knowledge, then knowledge dissemination among the organization can be noticed. The knowledge transferred by the organization to the employees causes the employees to become more loyal towards the brand (Schau, Muñiz Jr, \& Arnould, 2009; Tuli, Kohli, \& Bharadwaj, 2007). Hence a positive relationship is expected. These associations are hypothesized as below in hypothesis 6, 7 and 8 .

H6. Openness has a significant positive effect on knowledge dissemination.

H7. Knowledge dissemination has a significant positive effect on role clarity.

H8. Knowledge dissemination has a significant positive effect on brand commitment.

Employee-based brand equity benefits are positively affected by the brand commitment (Pappu, Quester, \& Cooksey, 2005). When the employees are more committed to the brand and the organization, the benefits for the organization increase in terms of goodwill and revenues. Similarly the clarity of the role has a positive relationship with the EBBE benefits (Lieberman, 2004). An employee with clear views about its targets can be considerably beneficial for the company. The relationship between brand commitment and role clarity with EBBE benefits is shown in the hypotheses below. The major research framework is shown in Figure 1. 
IJMS 25 (1), 1-20 (2018)

H9. Brand commitment has a significant positive effect on EBBE benefits.

H10. Role clarity has a significant positive effect on EBBE benefits.

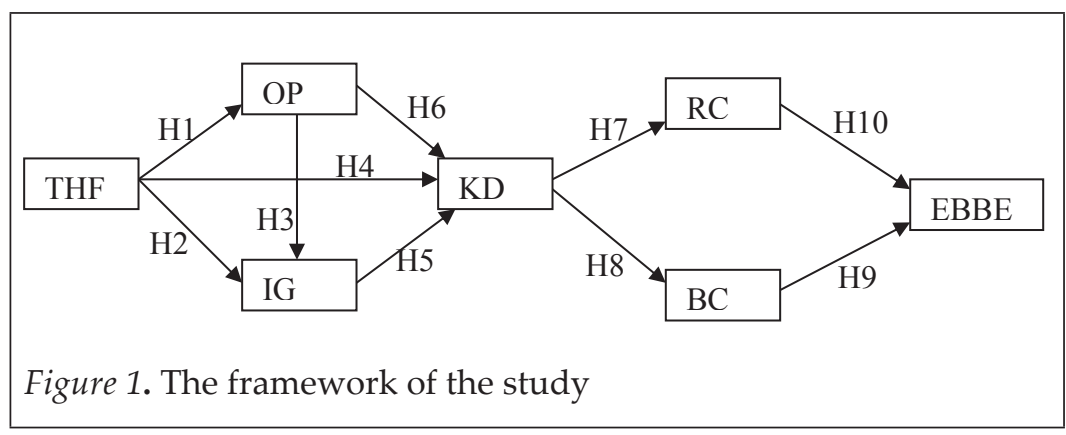

\section{Methodology}

\section{Measurement of Variables}

The study included six variables: " $\mathrm{H}$ " factor, information generation, knowledge dissemination, openness, role clarity, brand commitment and EBBE. The measurements of the related variables were referred to King and Grace (2010) as well as its references (Table 1).

Table 1

Studies Referred for Survey Instrument

\begin{tabular}{|c|c|}
\hline Dimension & Adapted from \\
\hline $\begin{array}{l}\text { Information } \\
\text { generation (IG) }\end{array}$ & $\begin{array}{l}\text { (Foreman and Money, 1995), (Lings and Greenley, } \\
\text { 2005) }\end{array}$ \\
\hline $\begin{array}{l}\text { Knowledge } \\
\text { dissemination (KD) }\end{array}$ & $\begin{array}{l}\text { (Foreman and Money, 1995), (Conduit and } \\
\text { Mavondo, 2001), (Lings and Greenley, 2005), } \\
\text { (King and Grace, 2010) }\end{array}$ \\
\hline Role clarity (RC) & $\begin{array}{l}\text { (Singh and Rhoads, 1991), (Kohli and Jaworski, } \\
\text { 1994), (Moorman, 1995) }\end{array}$ \\
\hline $\begin{array}{l}\text { Brand commitment } \\
\text { (BC) }\end{array}$ & (Ganesan \& Weitz, 1996), (Maltz \& Kohli, 1996) \\
\hline
\end{tabular}




\begin{tabular}{|c|c|}
\hline Dimension & Adapted from \\
\hline $\begin{array}{l}\text { Brand citizenship } \\
\text { behavior }(B C B)\end{array}$ & (Burmann \& Zeplin, 2005) \\
\hline $\begin{array}{l}\text { Employee } \\
\text { satisfaction (ES) }\end{array}$ & $\begin{array}{l}\text { (Netemeyer, Boles, McKee, \& McMurrian, 1997), } \\
\text { (Hartline and Ferrell, 1996), (King \& Grace, 2010) }\end{array}$ \\
\hline $\begin{array}{l}\text { Employee intention } \\
\text { to stay (EIS) }\end{array}$ & (Good, Page Jr., \& Young, 1996) \\
\hline $\begin{array}{l}\text { Positive employee } \\
\text { WOM (PEWoM) }\end{array}$ & $\begin{array}{l}\text { (Bloemer \& Odekerken-Schröder, 2006), (King \& } \\
\text { Grace, 2010) }\end{array}$ \\
\hline $\begin{array}{l}\text { Management } \\
\text { support (MS) }\end{array}$ & $\begin{array}{l}\text { (Kelley, Longfellow, \& Malehorn, 1996), (Wayne, } \\
\text { Shore, and Liden, 1997) }\end{array}$ \\
\hline $\begin{array}{l}\text { Organisation } \\
\text { socialisation (OS) }\end{array}$ & (Taormina, 1994) \\
\hline $\begin{array}{l}\text { Employee attitude } \\
\text { towards job (EATJ) }\end{array}$ & $\begin{array}{l}\text { (Naudé, Desai, \& Murphy, 2003), (Netemeyer, } \\
\text { Boles, McKee, \& McMurrian, 1997), (King \& } \\
\text { Grace, 2010) }\end{array}$ \\
\hline $\begin{array}{l}\text { Employee } \\
\text { involvement (EI) }\end{array}$ & (Conduit \& Mavondo, 2001), (King \& Grace, 2010) \\
\hline $\begin{array}{l}\text { The "H" factor } \\
\text { (THF) }\end{array}$ & $\begin{array}{l}\text { (Herington, 2003), (Herington, Scott, \& Johnson, } \\
\text { 2005), (King \& Grace, 2010) }\end{array}$ \\
\hline
\end{tabular}

A paper and pen survey was subsequently conducted with the senior management of small and medium size enterprises to find out the importance of this relatively new concept of employee-based brand equity in China. Obtaining data from the senior level staff of the firm proved difficult; hence an alternative approach was adopted, namely a request for participation email was sent to the companies. Those who replied to the email and confirmed their participation were then contacted and visited after prior appointment. China, being a non-English speaking country still has few fluent English speakers. Keeping in view this consideration, the original questionnaire was translated into Chinese. While translating the questionnaire into the Chinese language it was ensured that the meanings/phrases of the questionnaire were unaltered. Lack of willingness to participate was also an important issue. The four-stage survey design process used by the principal authors of the survey instrument had already negated the limitation of validity of the instrument. Data from 192 executive level staff of the Chinese Small and Medium Enterprises (SMEs) was 
considered for this research after following appropriate data cleaning procedures. The data analysis suggested that the employee-based brand equity was structured and evaluated by the same tools which were being used in the study as the explanatory variables.

\section{Sample Characteristics}

As a result of purposive sampling, 192 respondents formed the basis of this study's empirical analysis. Males represented the majority of the sample $(62.5 \%)$ while the remaining $(37.5 \%)$ were females. More than half $(66.7 \%$ or 128$)$ respondents were married while 61 of them (33.3\%) were unmarried. Regarding age, the largest representation was the $26-30$ year range ( $31.3 \%$ ), i.e. 60 respondents, while the least were in the 31-35 year range (14.6\%), i.e. 28 respondents. Those in the age range of 36-40 years had the largest representation with 40 respondents (20.8\%). Those above 40 years constituted $17.2 \%$ (33 respondents) and those below 25 years of age made up $16.1 \%$ (31 respondents) of the total. About half of the respondents had bachelor degrees while the remaining mostly had higher levels of education with $14.6 \%$ having masters degrees and $19.8 \%$ having professional degrees. Very few were holders of high school diploma (14\%), associate $(7 \%)$ and doctoral degree holders (4\%). As the study was based on the higher management level (middle and senior level staff) of Chinese small and medium enterprises, professional experience was of much crucial importance. Out of the total, 73 respondents (38 $\%$ ) had more than 7 years of professional experience. 11 respondents or $5.7 \%$ of the total had less than a year of experience. On careful observation it was noted that these were the respondents with the highest level of qualification and they may have started their career at a later age and hence had less experience then.

Table 2

Sample Characteristics

\begin{tabular}{cccc}
\hline & & Frequency & Percent \\
\hline \multirow{2}{*}{ Gender } & Male & 120 & 62.5 \\
& Female & 72 & 37.5 \\
\hline & & & continued
\end{tabular}


IJMS 25 (1), 1-20 (2018)

\begin{tabular}{|c|c|c|c|}
\hline & & Frequency & Percent \\
\hline \multirow{2}{*}{ Marital status } & Married & 128 & 66.7 \\
\hline & Unmarried & 62 & 33.3 \\
\hline \multirow{5}{*}{ Age range } & Below 25 years & 31 & 16.1 \\
\hline & $26-30$ years & 60 & 31.3 \\
\hline & 31-35 years & 28 & 14.6 \\
\hline & $36-40$ years & 40 & 20.8 \\
\hline & Above 40 years & 33 & 17.2 \\
\hline \multirow{7}{*}{ Education } & High school & 14 & 7.3 \\
\hline & Associate degree & 7 & 3.6 \\
\hline & Bachelors degree & 94 & 49.0 \\
\hline & Masters degree & 28 & 14.6 \\
\hline & Professional degree & 38 & 19.8 \\
\hline & Trade/Technical & 7 & 3.6 \\
\hline & Doctorate degree & 4 & 2.1 \\
\hline \multirow{5}{*}{$\begin{array}{l}\text { Professional } \\
\text { experience }\end{array}$} & Less than 1 year & 11 & 5.7 \\
\hline & $1-3$ years & 34 & 17.7 \\
\hline & 3-5 years & 43 & 22.4 \\
\hline & 5-7 years & 31 & 16.1 \\
\hline & More than 7 years & 73 & 38.0 \\
\hline
\end{tabular}

\section{Results}

Table 3 below shows the descriptive analysis of the data. The mean values and standard deviations are shown against each dimension. Skewness and kurtosis values show the normality of the data. All the values in these four columns depicts the normal distribution of the responses. This verifies that the model of the study is valid and the questionnaire is also based on realities. This part of the descriptive analysis results depict that the instrument and the responses are is normal and show the strong impact on the study. Furthermore, the values of cronbach alpha are also given in the table. All the values in this column are in the acceptable range and reliability of the survey instrument is also proved which holds a firm ground for the usage of the instrument. 
IJMS 25 (1), 1-20 (2018)

Table 3

Descriptive Analysis

\begin{tabular}{|c|c|c|c|c|c|}
\hline \multirow{2}{*}{ Dimension } & \multicolumn{2}{|c|}{$\begin{array}{l}\text { Descriptive } \\
\text { statistics }\end{array}$} & \multicolumn{2}{|c|}{$\begin{array}{l}\text { Normality } \\
\text { assessment }\end{array}$} & \multirow{2}{*}{$\begin{array}{c}\text { Cronbach } \\
\text { Alpha }\end{array}$} \\
\hline & Mean & $\begin{array}{l}\text { Standard } \\
\text { Deviation }\end{array}$ & Skewness & Kurtosis & \\
\hline $\begin{array}{l}\text { Information generation } \\
\qquad(\mathrm{IG})\end{array}$ & 11.6555 & 4.46449 & .192 & -.815 & .938 \\
\hline $\begin{array}{c}\text { Knowledge } \\
\text { dissemination (KD) }\end{array}$ & 10.9524 & 4.77529 & .432 & -.837 & .954 \\
\hline Role clarity (RC) & 10.8496 & 4.24045 & .275 & -.883 & .929 \\
\hline Brand commitment (BC) & 11.7083 & 4.71916 & .658 & .920 & .896 \\
\hline $\begin{array}{l}\text { Brand citizenship } \\
\text { behavior }(\mathrm{BCB})\end{array}$ & 11.1384 & 4.18043 & .170 & -.928 & .852 \\
\hline $\begin{array}{l}\text { Employee satisfaction } \\
\text { (ES) }\end{array}$ & 13.5312 & 3.35649 & -.483 & -.249 & .935 \\
\hline $\begin{array}{l}\text { Employee intention to } \\
\text { stay (EIS) }\end{array}$ & 13.5872 & 3.92141 & .159 & -.190 & .760 \\
\hline $\begin{array}{l}\text { Positive employee } \\
\text { WOM (PEWoM) }\end{array}$ & 11.4388 & 4.21973 & .288 & -.531 & .907 \\
\hline Management S(MS) & 11.1198 & 4.52732 & .243 & -.774 & .994 \\
\hline $\begin{array}{c}\text { Organisation } \\
\text { socialisation (OS) }\end{array}$ & 11.8273 & 4.17315 & .298 & -.693 & .924 \\
\hline $\begin{array}{l}\text { Employee attitude } \\
\text { towards their job (EATJ) }\end{array}$ & 13.2217 & 3.69964 & .054 & -.206 & .926 \\
\hline $\begin{array}{l}\text { Employee involvement } \\
\text { (EI) }\end{array}$ & 10.8811 & 4.17511 & .360 & -.707 & .950 \\
\hline $\begin{array}{l}\text { The human factor } \\
\text { (THF) }\end{array}$ & 12.1325 & 4.03230 & .294 & -.627 & .961 \\
\hline Multivariate & & & 85.851 & 30.118 & \\
\hline
\end{tabular}

The correlation analysis is shown in Table 4 below. The basis for the convergent validity is correlation of items theoretically linked together 
(Lewis, Templeton, \& Byrd, 2005). The bivariate correlation analysis was conducted at the 0.001 confidence level. All the constructs showed the correlation and the values ranged from 0.264 to 0.875 . Hence this exploratory analysis depicted that high correlated constructs and validity were confirmed (Churchill \& Lacobucci, 2002).

Table 4

Correlation Analysis

\begin{tabular}{|c|c|c|c|c|c|c|c|c|c|c|c|c|}
\hline & IG & $\mathrm{KD}$ & $\mathrm{RC}$ & $\mathrm{BC}$ & $\mathrm{BCB}$ & ES & EIS & PEWoM & MS & OS & EATJ & EI \\
\hline $\mathrm{KD}$ & $.843^{* *}$ & & & & & & & & & & & \\
\hline RC & $.774^{* *}$ & $.854^{* *}$ & & & & & & & & & & \\
\hline BC & $.708^{* *}$ & $.723^{* *}$ & $.723^{* *}$ & & & & & & & & & \\
\hline ВСВ & $.796^{* *}$ & $.843^{* *}$ & $.831^{* *}$ & $.865^{* *}$ & & & & & & & & \\
\hline ES & $.398^{* *}$ & $.340^{* *}$ & $.264^{* *}$ & $.452^{* *}$ & $.487^{* *}$ & & & & & & & \\
\hline EIS & $.372^{* *}$ & $.322^{* *}$ & $.330^{* *}$ & $.534^{* *}$ & $.516^{* *}$ & $.676^{* *}$ & & & & & & \\
\hline PEWoM & $.679^{* * *}$ & $.751^{* *}$ & $.762^{* *}$ & $.741^{* *}$ & $.821^{* *}$ & $.511^{* *}$ & $.580^{* * *}$ & & & & & \\
\hline MS & $.765^{* *}$ & $.789^{* *}$ & $.814^{* *}$ & $.744^{* *}$ & $.839^{* *}$ & $.365^{* *}$ & $.500^{* *}$ & $.814^{* * *}$ & & & & \\
\hline OS & $.685^{* *}$ & $.777^{* *}$ & $.779^{* *}$ & $.726^{* *}$ & $.804^{* *}$ & $.429^{* *}$ & $.511^{* *}$ & $.781^{* *}$ & $.772^{* *}$ & & & \\
\hline EATJ & $.412^{* *}$ & $.379^{* *}$ & $.381^{* *}$ & $.507^{* *}$ & $.512^{* *}$ & $.695^{* *}$ & $.744^{* *}$ & $.595^{* *}$ & $.447^{* *+}$ & $.547^{* *}$ & & \\
\hline EI & $.771^{* * *}$ & $.828^{* *}$ & $.875^{* *}$ & $.695^{* *}$ & $.809^{* *}$ & $.352^{* *}$ & $.375^{* *}$ & $.772^{* *}$ & $.816^{* *}$ & $.769^{* * *}$ & $.480^{* * *}$ & \\
\hline THF & $.689^{* *}$ & $.713^{* *}$ & $.708^{* *}$ & $.718^{* *}$ & $.778^{* *}$ & $.486^{* *}$ & $.610^{* *}$ & $.776^{* *}$ & $.789^{* *}$ & $.774^{* *}$ & $.661^{* *}$ & $.784^{*}$ \\
\hline
\end{tabular}

The model fit indices show that the model is a little good to some extent, since the chi-square is 4.120 , which is between the interval of $[2,5]$. However, the other indices are a little low. Maybe a major problem is the sample size which is a little small as only 192 people were surveyed. Further improvements in the results are possible if the number of respondents can be increased as per the guidelines given in the literature. Table 5 below shows the model fit index results.

Table 5

Model Fit Index

\begin{tabular}{lc}
\hline The index & The Value \\
\hline Chi-square/freedom & 4.120 \\
NFI & 0.743 \\
\hline
\end{tabular}

continued 
IJMS 25 (1), 1-20 (2018)

\begin{tabular}{lc}
\hline The index & The Value \\
\hline TLI & 0.774 \\
CFI & 0.791 \\
RMSEA & 0.128 \\
\hline
\end{tabular}

The path analysis shows that most of the hypotheses are supported (Table 6). The only hypothesis that is not significant is H4, which is partially significant. Hence, the human factor shows a weaker relationship with knowledge dissemination.

Table 6

The Significance of the Paths

\begin{tabular}{llllllll}
\hline & & & Estimate & S.E. & C.R. & P & Label \\
\hline OP & $<---$ & THF & .754 & .050 & 15.138 & $* * *$ & par_32 \\
IG & $<---$ & THF & -.292 & .145 & -2.017 & .044 & par_34 \\
IG & $<---$ & OP & 1.268 & .193 & 6.584 & $* * *$ & par_35 \\
KD & $<---$ & THF & -.482 & .137 & -3.514 & $* * *$ & par_33 \\
KD & $<---$ & IG & .206 & .107 & 1.922 & .055 & par_36 \\
KD & $<---$ & OP & 1.485 & .256 & 5.806 & $* * *$ & par_37 \\
RC & $<---$ & KD & .771 & .056 & 13.839 & $* * *$ & par_38 \\
BC & $<---$ & KD & .752 & .061 & 12.404 & $* * *$ & par_39 \\
EBBE & $<---$ & BC & .654 & .055 & 11.956 & $* * *$ & par_40 \\
EBBE & $<---$ & RC & .359 & .052 & 6.922 & $* * *$ & par_41 \\
\hline
\end{tabular}

Table 7 shows the summarized form of the results. It can be clearly seen that ofter than the hypothesized relationship among the H Factor and knowledge dissemination all other relationships were noted as supported through the data analysis.

Table 7

Hypotheses Results

H1. The "H" factor has a significant positive effect on Supported openness.

H2. The "H" factor has a significant positive effect on Supported information generation.

H3. Openness has a significant positive effect on information Supported generation. 


\begin{tabular}{lll}
\hline H4. & The "H" factor has a significant positive effect on & Rejected \\
knowledge dissemination. & \\
H5. & $\begin{array}{l}\text { Information generation has a significant positive effect } \\
\text { on knowledge dissemination. }\end{array}$ & Supported \\
H6. & $\begin{array}{l}\text { Openness has a significant positive effect on knowledge } \\
\text { dissemination. }\end{array}$ & Supported \\
H7. & $\begin{array}{l}\text { Knowledge dissemination has a significant positive effect } \\
\text { on role clarity. }\end{array}$ & \\
H8. & $\begin{array}{l}\text { Knowledge dissemination has a significant positive effect } \\
\text { on brand commitment. }\end{array}$ & \\
H9. & $\begin{array}{l}\text { Brand commitment has a significant positive effect } \\
\text { on EBBE benefits. }\end{array}$ & Supported \\
H10. Role clarity has a significant positive effect on EBBE & Supported \\
benefits. & \\
\hline
\end{tabular}

\section{Conclusion}

The study reaffirmed the findings of Tavassoli et al. (2014) and King and Grace (2010) where the measurement of brand value to a firm and its effects on the attitudes and behaviors of its employees were reported. It is proved through the results that executives may even accept lower pay and monetary benefits of their affiliation when the brand is strong. This is consistent with the identity theory; this effect is stronger for CEOs compared to other top executives, as well as for younger executives. This study is therefore pertinent to combine all internal brand management aspects. It is recommended that big brands have to manage employee-based brand equity for greater financial output in the years to come. Specifically the results of descriptive statistics, reliability and the correlation tests confirmed almost all the hypotheses. It shows that in Chinese SMEs the employee-based brand equity is prevailing and it results in huge benefits to the firms. It is also confirmed that the dissemination of the knowledge increases the EBBE benefits (Gagnon, 2011). Additionally, the employees who are aware of delivering brand promise also supported firms' benefits (Hall, 2008). As per the Job Satisfaction Survey of Society for Human Resource Management (SHRM, 2009), employee benefits are important for employee-job satisfaction. This helps in retaining the current and future staff (Shaari, Salleh, \& HUSSIN, 2015). Thompson and Prottas (2006) found lower stress and reduced turnover intention when employees received social support from the organization. Employee commitment towards the brand results in EBBE benefits as it results 
in increasing the revenues (Wallace, Chernatony, and Buil, 2013). Similarly the significant positive relationships of the other hypothesis are also accepted. Overall the findings match those of King and Grace (2010). This study will encourage the Chinese SMEs to motivate and encourage their employees to get the maximum benefits out of it. Also it supports the idea that employee-brand management techniques such as brand communication trainings, employee role clarity initiative, belief on information sharing, orientation and improving employees' understanding about organizational goals is a prolific investment and leads toward measurable organizational benefits. The contribution of this paper to the subject of brand equity, marketing and HR is significant as employee-brand equity is a competitively new subject and in particular examines lower executive employees' perceptions about their organization. None of us can deny the Chinese interest in foreign direct investment in various locations around the world. So this research is a good guide for Chinese entrepreneurs. This model will further help enrich traditional brand management, increase organizational understanding and how to engender positive employee actions. "Made in China" products are available and famous all around the world. Being a major global economic power, China holds great importance in the continent of Asia as well as around the world. So to address the Chinese perspective, the research was conducted.

\section{References}

Aselage, J., \& Eisenberger, R. (2003). Perceived organizational support and psychological contracts: A theoretical integration. Journal of Organizational Behavior, 24(5), 491-509.

Biswas, M. K., \& Suar, D. (2016). Antecedents and consequences of employer branding. Journal of Business Ethics, 136(1), 57-72.

Bloemer, J., \& Odekerken-Schröder, G. (2006). The role of employee relationship proneness in creating employee loyalty. International Journal of Bank Marketing, 24(4), 252-264.

Bray, S. R., Beauchamp, M. R., Eys, M. A., \& Carron, A. V. (2005). Does the need for role clarity moderate the relationship between role ambiguity and athlete satisfaction? Journal of Applied Sport Psychology, 17(4), 306-318.

Brexendorf, T. O., \& Kernstock, J. (2007). Corporate behaviour vs brand behaviour: Towards an integrated view? Journal of Brand Management, 15(1), 32-40. 
Brown, S. P., \& Lam, S. K. (2008). A meta-analysis of relationships linking employee satisfaction to customer responses. Journal of Retailing, 84(3), 243-255.

Burmann, C., \& Zeplin, S. (2005). Building brand commitment: A behavioural approach to internal brand management. Journal of Brand Management, 12(4), 279-300.

Cadman, B., Carter, M. E., \& Lynch, L. J. (2012). Executive compensation restrictions: Do they restrict firms' willingness to participate in TARP? Journal of Business Finance \& Accounting, 39(7-8), 997-1027.

Carter, N. (2010). Clinical nurse specialists and nurse practitioners: Title confusion and lack of role clarity. Nursing Leadership, 189.

Christodoulides, G., \& De Chernatony, L. (2010). Consumer-based brand equity conceptualization and measurement: A literature review. International Journal of Market Research, 52(1), 43-66.

Churchill, G. A., \& Iacobucci, D. (2006). Marketing research: Methodological foundations. New York: Dryden Press.

Conduit, J., \& Mavondo, F. T. (2001). How critical is internal customer orientation to market orientation? Journal of Business Research, 51(1), 11-24.

Cox, A., Zagelmeyer, S., \& Marchington, M. (2006). Embedding employee involvement and participation at work. Human Resource Management Journal, 16(3), 250-267.

De Chernatony, L. (1999). Brand management through narrowing the gap between brand identity and brand reputation. Journal of Marketing Management, 15(1-3), 157-179.

De Chernatony, L., \& Cottam, S. (2006). Internal brand factors driving successful financial services brands. European Journal of Marketing, 40(5/6), 611-633.

DeChernatony, L., Cottam, S., \& Segal-Horn, S. (2006). Communicating services brands' values internally and externally. The Service Industries Journal, 26(8), 819-836.

Foreman, S. K., \& Money, A. H. (1995). Internal marketing: Concepts, measurement and application. Journal of Marketing Management, 11(8), 755-768.

Gagnon, M. L. (2011). Moving knowledge to action through dissemination and exchange. Journal of Clinical Epidemiology, 64(1), 25-31.

Galotti, K. M. (2017). Cognitive psychology in and out of the laboratory. Sage Publications. Thousand Oaks, California.

Ganesan, S., \& Weitz, B. A. (1996). The impact of staffing policies on retail buyer job attitudes and behaviors. Journal of Retailing, 72(1), 31-56. 
Good, L. K., Page Jr, T. J., \& Young, C. E. (1996). Assessing hierarchical differences in job-related attitudes and turnover among retail managers. Journal of the Academy of Marketing Science, 24(2), 148156.

Greco, P., Laschinger, H. K. S., \& Wong, C. (2006). Leader empowering behaviours, staff nurse empowerment and work engagement/ burnout. Nursing Leadership, 19(4), 41-56.

Hall, M. (2008). The effect of comprehensive performance measurement systems on role clarity, psychological empowerment and managerial performance. Accounting, Organizations and Society, 33(2), 141-163.

Herington, C. A. (2003). Developing and testing a model of firm-employee relationship strength for use in relationship marketing situations. Southern Cross University.

Herington, C., Scott, D., \& Johnson, L. W. (2005). Focus group exploration of firm-employee relationship strength. Qualitative Market Research: An International Journal, 8(3), 256-276.

Kelley, S. W., Longfellow, T., \& Malehorn, J. (1996). Organizational determinants of service employees' exercise of routine, creative, and deviant discretion. Journal of Retailing, 72(2), 135-157.

King, C., \& Grace, D. (2005). Exploring the role of employees in the delivery of the brand: A case study approach. Qualitative Market Research: An International Journal, 8(3), 277-295.

King, C., \& Grace, D. (2010). Building and measuring employee-based brand equity. European Journal of Marketing, 44(7/8), 938-971.

King, C., Grace, D., \& Funk, D. C. (2012). Employee brand equity: Scale development and validation. Journal of Brand Management, 19(4), 268-288.

Kohli, A. K., \& Jaworski, B. J. (1994). The influence of coworker feedback on salespeople. The Journal of Marketing, 82-94.

Kumar, S. S. (2011). The influence of organizational culture as moderator between person organization (P-O) Fit and work attitudes. International Journal of Management Studies, 18(1), pp. 71-97.

Lewis, B. R., Templeton, G. F., \& Byrd, T. A. (2005). A methodology for construct development in MIS research. European Journal of Information Systems, 14(4), 388-400.

Lieberman, A. (2004). Confusion regarding school counselor functions: School leadership impacts role clarity. Education, 124(3), 552559.

Lings, I. N. (2004). Internal market orientation: Construct and consequences. Journal of Business Research, 57(4), 405-413. 
Lings, I. N., \& Greenley, G. E. (2005). Measuring internal market orientation. Journal of Service Research, 7(3), 290-305.

Maltz, E., \& Kohli, A. K. (1996). Market intelligence dissemination across functional boundaries. Journal of Marketing Research, 47-61.

Meredith, J. R., Steward, M. D., \& Lewis, B. R. (2011). Knowledge dissemination in operations management: Published perceptions versus academic reality. Omega, 39(4), 435-446.

Mizik, N., \& Jacobson, R. (2008). The financial value impact of perceptual brand attributes. Journal of Marketing Research, 45(1), 15-32.

Moorman, C. (1995). Organizational market information processes: Cultural antecedents and new product outcomes. Journal of Marketing Research, 318-335.

Mowday, R. T., Porter, L. W., \& Steers, R. M. (2013). Employeeorganization linkages: The psychology of commitment, absenteeism, and turnover. Cambridge Academic Press.

Naudé, P., Desai, J., \& Murphy, J. (2003). Identifying the determinants of internal marketing orientation. European Journal of Marketing, 37(9), 1205-1220.

Netemeyer, R. G., Boles, J. S., McKee, D. O., \& McMurrian, R. (1997). An investigation into the antecedents of organizational citizenship behaviors in a personal selling context. The Journal of Marketing, 85-98.

Pappu, R., Quester, P. G., \& Cooksey, R. W. (2005). Consumerbased brand equity: Improving the measurement-empirical evidence. Journal of Product \& Brand Management, 14(3), 143-154.

Poulis, A.,Poulis, A., Wisker,Z., \&Wisker,Z.(2016). Modeling employeebased brand equity (EBBE) and perceived environmental uncertainty (PEU) on a firm's performance. Journal of Product $\mathcal{E}$ Brand Management, 25(5), 490-503.

Priyadarshi, P. (2011). Employer brand image as predictor of employee satisfaction, affective commitment \& turnover. Indian Journal of Industrial Relations, 510-522.

Reed, A., Forehand, M. R., Puntoni, S., \& Warlop, L. (2012). Identitybased consumer behavior. International Journal of Research in Marketing, 29(4), 310-321.

Rust, R. T., \& Oliver, R. L. (2000). Should we delight the customer? Journal of the Academy of Marketing Science, 28(1), 86-94.

Schau, H. J., Muñiz Jr, A. M., \& Arnould, E. J. (2009). How brand community practices create value. Journal of Marketing, 73(5), 30-51. 
Schlager, T., Bodderas, M., Maas, P., \& Luc Cachelin, J. (2011). The influence of the employer brand on employee attitudes relevant for service branding: An empirical investigation. Journal of Services Marketing, 25(7), 497-508.

Schütze, B., \& Schütze, C. (2012). The Ecstasy of Communication. New York: Semiotext(e).

Shaari, H., Salleh, S. M., \& Hussin, Z. (2015). Employees brand citizenship behaviour: Front-liner versus backstage employees'perspective. IJMS, 22(1), 23-32.

Singh, J., \& Rhoads, G. K. (1991). Boundary role ambiguity in marketing-oriented positions: A multidimensional, multifaceted operationalization. Journal of Marketing Research, 328-338.

Society for Human Resource Management (SHRM). (2009). Examining paid leave in the workplace: Helping your organization attract and retain talented employees. A survey report.

Taormina, R. J. (1994). The organizational socialization inventory. International Journal of Selection and Assessment, 2(3), 133-145.

Tavassoli, N. T., Sorescu, A., \& Chandy, R. (2014, December). Employee-based brand equity: Why firms with strong brands pay their executives less. American Marketing Association.

Thompson, C. A., \& Prottas, D. J. (2006). Relationships among organizational family support, job autonomy, perceived control, and employee well-being. Journal of Occupational Health Psychology, 10(4), 100-118.

Tuli, K. R., Kohli, A. K., \& Bharadwaj, S. G. (2007). Rethinking customer solutions: From product bundles to relational processes. Journal of Marketing, 71(3), 1-17.

Wallace, E., de Chernatony, L., \& Buil, I. (2013). Building bank brands: How leadership behavior influences employee commitment. Journal of Business Research, 66(2), 165-171.

Wayne, S. J., Shore, L. M., \& Liden, R. C. (1997). Perceived organizational support and leader-member exchange: A social exchange perspective. Academy of Management Journal, 40(1), 82-111.

Yang, J., \& Lan, H. (2009, September). Psychological capital as mediator in relationship among organizational socialization, knowledge integration and sharing. Management and Service Science, 2009. MASS'09. International Conference on IEEE (pp. 1-4). 